\begin{tabular}{|c|c|c|}
\hline & 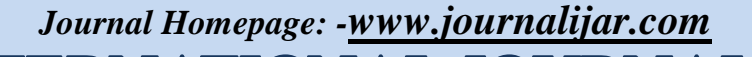 & $\begin{array}{l}\text { INTERNATIONAL JOURNAL OF } \\
\text { ADVANCED RESEARCH (JJAR) }\end{array}$ \\
\hline 0. $2320-5407$ & $\begin{array}{c}\text { Article DOI:10.21474/IJAR01/8849 } \\
\text { DOI URL: http://dx.doi.org/10.21474/IJAR01/8849 }\end{array}$ & \\
\hline
\end{tabular}

RESEARCH ARTICLE

\title{
AN OVERVIEW ON OCCUPATIONAL HAZARDS IN AYURVEDA.
}

Dr. Vibha.S ${ }^{1}$ and Rashmi. B. $\mathbf{M}^{2}$.

1. PG Scholar, Dept of PG Studies in Roga Nidana and Vikriti Vignana, Government Ayurvedic Medical College, Bengaluru.

2. Assistant Professor, Dept of PG Studies in Roga Nidana and Vikriti Vignana, Government Ayurvedic Medical College, Bengaluru.

\section{Manuscript Info}

\section{Manuscript History}

Received: 08 February 2019

Final Accepted: 10 March 2019

Published: April 2019

Key words:-

Udyoga, occupation, Purushartha, hazards.

\section{Abstract}

" उद्योगं पुरुषलक्षणम् " This is a very famous age-old adage which means that an occupation / job is the identity of an individual, which indicates the importance of it in each person's life. Ayurveda also upholds the importance of occupation as a means and one of the steps in attaining Purusharthas or the ultimate goals in life as decreed by our Indian ethos.

The body which is believed to serve as the prime instrument in attaining Purusharthas should not suffer as a result of one's occupation. Occupational hazards are various diseases, trauma, injuries and other mishaps on multiple levels like physical, mental, emotional, social and spiritual that a person encounters because of the chosen occupation. The present study is a preliminary effort to shed light on the occupational hazards, understanding them and managing them through Ayurveda.

Copy Right, IJAR, 2019,. All rights reserved.

\section{Introduction:-}

An occupation, apart from being a means of livelihood, is also a source of identity for a person in the society. It also helps in the growth and evolution of a person physically, mentally, emotionally, spiritually and socially.

Synonyms of 'occupation': employment, job, work, profession, labour.

Any dangers or mishaps encountered at the work front are called 'occupational hazards'. These work-related accidents are the biggest problems in developing countries, while work-related diseases are more frequent in industrialized countries.

The occupational health represents a dynamic equilibrium or adjustment between the worker and his occupational environment. When this equilibrium is hampered by any numerous causes, occupational hazards take place, which lead to the incurring of heavy loss both by the employee and the employer or the employment institution.

This article is a preliminary attempt at the understanding and management of occupational hazards using Ayurvedic principles. 


\section{Aims \& objectives:}

1. Understanding and managing of occupational hazards through Ayurveda.

2. Knowledge about different classes of occupational hazards.

3. Devising a standardized pre-placement examination before recruitment of people to various occupations, as per Ayurveda.

\section{Materials \& methods:-}

Careful perusal of the Bruhattrayees, the Greater Triad of Ayurvedic literature like Sushrutha Samhitha, Charaka Samhitha and Ashtanga Hridaya along with the contemporary medical textbooks on social and preventive medicine, namely, Park's Book of Preventive and Social Medicine is done.

\section{Discussion:-}

Occupational health and hazards through the ages :

1. In the past, it was customary to think of occupational health as entirely related to factories and mines; hence the terms 'industrial hygiene' and 'industrial health' were used. But modern concepts of occupational health accepts all types of employment including mercantile and commercial enterprises, service trades, forestry and agriculture and includes the subjects of industrial accidents, toxicology in relation to industrial hazards, industrial rehabilitation and occupational psychology.

2. ERGONOMICS (ergon=work, nomos=law)- It involves designing of machines, tools, equipment and manufacturing processes, lay-out of the places of work and environment in order to achieve greater efficiency of both man and machine. The application of ergonomics has made a significant contribution to reducing industrial accidents and to the overall health and efficiency of the workers. ${ }^{\text {la }}$

3. International Labour Organization (ILO) was started in 1919 as one of the UN agencies. It serves as an international forum for all work-related issues. It is also concerned with international labour standards, social protection and work opportunities for all.

Fact about occupational hazards:

Occupational Health services are non-existent for a majority-85\% of Indian workers in unorganized sector. Of the global 1.9 million cases, $17 \%$ are contributed by India. The adverse occupational factors cost $2 \%-14 \%$ of gross national product. ${ }^{2}$

\section{Prevention of occupational diseases ${ }^{1 \mathrm{~b}}$ :}

achieved by

1. Medical Measures like pre-placement examination, periodical examination, medical and health care services, supervision of working environment, maintenance and analysis of records and health education \& counseling.

2. Engineering Measures like design of building, good housekeeping, general ventilation, mechanization, substitution, dusts, enclosure, isolation, local exhaust ventilation, protective devices, environmental monitoring, statistical monitoring and research.

3. Legislation like The Factories Act, The Employees State Insurance Act.

\section{Occupational hazards:}

Broadly classified into five types. They are: Physical, Chemical, Biological, Mechanical and Pycho-social Hazards.

All these take place by three types of interactions in the working environment ${ }^{1 \mathbf{c}}$, namely:

1. Man and physical, chemical and biologic agents

2. Man and machine

3. Man and man

There a number of occupational hazards/diseases and with the advent of industrialization and evolution of newer technologies, there's been an increase in the former as well. This article deals with a few selected occupational hazards.

Physical hazards:

\begin{tabular}{|l|l|c|l|}
\hline $\begin{array}{l}\text { PHYSICAL } \\
\text { AGENTS }\end{array}$ & निदानम्/OCCUPATION & PATHOLOGICAL FINDINGS & MANAGEMENT \\
\hline HEAT & Foundries, glass and steel & 1. Burns-superficial & Sheeta pralepas like \\
\hline
\end{tabular}




\begin{tabular}{|c|c|c|c|}
\hline & $\begin{array}{l}\text { industries, mines, cotton and } \\
\text { jute industries. }\end{array}$ & $\begin{array}{l}\text { involving epidermis, } \\
\text { partial thickness } \\
\text { involving dermis and } \\
\text { full-thickness involving } \\
\text { sub-q tissue and } \\
\text { muscles-rapid shift of } \\
\text { bodily fluids into the } \\
\text { interstitial } \\
\text { compartments; } \\
\text { development of } \\
\text { hypermetabolic } \text { state. } \\
\text { Heat cramps-loss of } \\
\text { electrolytes and } \\
\text { voluntary muscle } \\
\text { cramps } \\
\text { Heat exhaustion- } \\
\text { failure of CVS to } \\
\text { compensate for } \\
\text { hypovolemia following } \\
\text { water loss. } \\
\text { Heat stroke- } \\
\text { CBT }>40^{\circ} \mathrm{C} \text {, generalized } \\
\text { vasodilation and } \\
\text { peripheral pooling of } \\
\text { blood }\end{array}$ & $\begin{array}{l}\text { Chandana,Ushira. } \\
\text { Application of Shata } \\
\text { dhouta ghrita in moderate } \\
\text { and mild degree burns. }\end{array}$ \\
\hline COLD & Soldiers, homeless people. & $\begin{array}{l}\text { 1. Direct effect-disruption } \\
\text { of cells by } \\
\text { crystallization of intra } \\
\text { and extra-cellular water } \\
\text { 2. Indirect effect-period } \\
\text { of ischemia, hypoxic } \\
\text { changes and infarction } \\
\text { of the affected tissues. }\end{array}$ & $\begin{array}{l}\text { Application of sheeta } \\
\text { prashamaka lepas like } \\
\text { Agurvadi, } \\
\text { Punarnava mandura, } \\
\text { Makaradhvaja Rasa for } \\
\text { enhancing oxygenation in } \\
\text { the body. } \\
\text { BrihatVata Chintamani in } \\
\text { infarct conditions. }\end{array}$ \\
\hline LIGHT & Dim lit or glares & $\begin{array}{l}\text { Eye strain, headache, } \\
\text { lachrymation, congestion around } \\
\text { the cornea, eye fatigue. }\end{array}$ & $\begin{array}{l}\text { Tarpana and Putapaka for } \\
\text { netras, seka, bidalaka and } \\
\text { parisheka using soothing } \\
\text { herbal preparations. } \\
\text { Also eye exercises along } \\
\text { with the above. }\end{array}$ \\
\hline NOISE & $\begin{array}{l}\text { Machineries, loud and blaring } \\
\text { noises }\end{array}$ & $\begin{array}{l}\text { 1. Auditory- Temporary } \\
\text { or permanent hearing } \\
\text { loss } \\
\text { 2. Non-auditory- } \\
\text { nervousness, fatigue, } \\
\text { impaired } \\
\text { communication of } \\
\text { speech, annoyance }\end{array}$ & $\begin{array}{l}\text { Karna poorana and karna } \\
\text { tarpana to strength the } \\
\text { auditory nerve. } \\
\text { Rasa dhathu poshana for } \\
\text { the remaining symptoms. }\end{array}$ \\
\hline VIBRATION & $\begin{array}{l}\text { Pneumatic tools like drills and } \\
\text { hammers }\end{array}$ & $\begin{array}{l}\text { Fine blood vessels of the fingers } \\
\text { become sensitive to spasm. }\end{array}$ & $\begin{array}{l}\text { Kashayas of Manjishtha } \\
\text { and Rasayana prayoga }\end{array}$ \\
\hline $\begin{array}{l}\text { UV } \\
\text { RADIATION }\end{array}$ & Arc welding & $\begin{array}{l}\text { Intense conjunctivitis, keratitis, } \\
\text { redness and pain in eyes. }\end{array}$ & Netra seka and bidalaka \\
\hline $\begin{array}{l}\text { IONIZING } \\
\text { RADIATION }\end{array}$ & $\begin{array}{l}\text { Medicine and industry like- } \\
\mathrm{X} \text {-rays and radio-active } \\
\text { isotopes }\end{array}$ & $\begin{array}{l}\text { Cell proliferation, production of } \\
\text { reactive oxygen species, } \\
\text { hypoxia, vascular damage. }\end{array}$ & $\begin{array}{l}\text { Rasayana and Vajikarana } \\
\text { yogas }\end{array}$ \\
\hline
\end{tabular}


CHEMICAL HAZARDS: The chemical hazards are on the increase with the introduction of newer and complex chemicals. Chemical agents act in three ways:

\begin{tabular}{|c|c|c|}
\hline DUST DISEASES & CAUSE & FEATURES \\
\hline SILICOSIS & $\begin{array}{l}\text { Inhalation of dust containing free silica or silicon } \\
\text { dioxide }\end{array}$ & $\begin{array}{r}\text { The higher the concentration of free } \\
\text { silica in the dust, the greater the } \\
\text { hazard. } \\
\text { Incubation period-few months to } 6 \\
\text { years of exposure. Characterized by } \\
\text { a dense 'nodular' fibrosis of 3-4mm } \\
\text { size. Accompanied with irritant } \\
\text { cough, dyspnoea on exertion, pain } \\
\text { in the chest. } \\
\text { 'Snow-storm' appearance in CXR. }\end{array}$ \\
\hline ANTHRACOSIS & Coal dust & $\begin{array}{l}\text { 2 Phases } \\
\text { 1. Simple pneumoconiosis-. } \\
\text { 2. } \\
\text { Progressive Fibrosis. }\end{array}$ \\
\hline BYSSINOSIS & Cotton fibre dust & $\begin{array}{l}\text { Chronic cough and progressive } \\
\text { dyspnoea, ending in chronic } \\
\text { bronchitis and emphysema. }\end{array}$ \\
\hline BAGASSOSIS & Bagasse or sugar cane dust & $\begin{array}{l}\text { Breathlessness, cough, haemoptysis } \\
\text { and slight fever. } \\
\text { Mottling of lungs in CXR. }\end{array}$ \\
\hline ASBESTOSIS & $\begin{array}{l}\text { Silicates of varying composition-silica combined } \\
\text { with bases like: } \mathrm{Mg}, \mathrm{Fe}, \mathrm{Ca}, \mathrm{Na} \text { and } \mathrm{Al} \text {. } \\
2 \text { Types of asbestos-serpentine and chrysotile. }\end{array}$ & $\begin{array}{c}\text { Fine dust deposited in the alveoli, } \\
\text { causing pulmonary fibrosis leading } \\
\text { to respiratory insufficiency and } \\
\text { death; also carcinoma of the } \\
\text { bronchus, mesothelioma of the } \\
\text { pleura or peritoneum. }\end{array}$ \\
\hline FARMER'S LUNG & Mouldy hay or grain dust & $\begin{array}{l}\text { Repeated attacks cause pulmonary } \\
\text { fibrosis and inevitable pulmonary } \\
\text { damage and cor pulmonale. }\end{array}$ \\
\hline
\end{tabular}

\section{Local action:}

Some chemicals cause dermatitis, eczema, ulcers and even cancer by primary irritant action; some cause dermatitis by an allergic reaction. Some chemicals, particularly the aromatic and amino compounds such as TNT and aniline are absorbed through the skin and cause systemic effects.

\section{Ingestion:}

Occupational diseases may also result from ingestion of chemical substances such as lead, mercury, arsenic, zinc, chromium, cadmium, phosphorus etc. Usually these substances are swallowed in minute amounts through contaminated food or cigarettes. Much of the ingested material is excreted through faeces and only a small proportion may reach the general blood circulation.

\section{Inhalation:}

Dust within the range of 0.5-3 microns is a health hazard, producing a lung disease known as PNEUMOCONIASIS, after a variable period of time. This disease gradually cripples a man by reducing his working capacity due to lung fibrosis and other complications. The threshold limit values for different dusts are different. The important dust diseases are:

\section{Biological hazards:}

Workers may be exposed to infective and parasitic agents at the place of work. The occupational diseases in this category are as follows-

\begin{tabular}{|l|l|l|l|}
\hline DISEASE & $\begin{array}{l}\text { CAUSATIVE } \\
\text { ORGANISM }\end{array}$ & $\begin{array}{l}\text { PATHOLOGICAL } \\
\text { FINDINGS }\end{array}$ & INCUBATION PERIOD \\
\hline BRUCELLOSIS & Brucellosis sp. & $\begin{array}{l}\text { Septicaemia, undulant } \\
\text { fevers, migratory }\end{array}$ & 2 months \\
\hline
\end{tabular}




\begin{tabular}{|c|c|c|c|}
\hline & & arthralgia & \\
\hline LEPTOSPIROSIS & Leptospira & $\begin{array}{l}\text { Biphasic disease-first } \\
\text { phase suddenly with chills, } \\
\text { intense headache, myalgia, } \\
\text { pain abdomen, } \\
\text { conjunctival suffusion, } \\
\text { skin rash. } \\
\text { Second phase with fever } \\
\text { and meningitis }\end{array}$ & $7-12$ days \\
\hline ANTHRAX & Bacillus anthracis & $\begin{array}{l}\text { A small blister with } \\
\text { surrounding swelling } \\
\text { which turns to painless } \\
\text { ulcer with a black centre } \\
\text { from skin. } \\
\text { Fever, chest pain, } \\
\text { shortness of breath from } \\
\text { inhalation. } \\
\text { Nausea, vomiting, diarrhea } \\
\text { or abdominal pain from } \\
\text { intestines. } \\
\text { Fever and abscess at the } \\
\text { site of drug injection. }\end{array}$ & 1 day-2 months \\
\hline HYDATIDOSIS & $\begin{array}{l}\text { Tapeworm of the } \\
\text { ECHINOCOCCUS type. }\end{array}$ & $\begin{array}{l}\text { Growing masses of cysts } \\
\text { localized in the lungs, } \\
\text { brain, heart and kidneys. }\end{array}$ & Many years \\
\hline PSITTACOSIS & Chlamydophila psittaci & $\begin{array}{l}\text { Atypical pneumonia, } \\
\text { mimics typhoid. }\end{array}$ & 5-19 days \\
\hline TETANUS & Clostridium tetani & $\begin{array}{l}\text { Muscle spasms, fever, } \\
\text { sweating, headache, high } \\
\text { BP, trouble swallowing. }\end{array}$ & 3-21 days \\
\hline ENCEPHALITIS & Viral or bacterial & $\begin{array}{l}\text { Inflammation of the brain- } \\
\text { headache, fever, } \\
\text { confusion, drowsiness, and } \\
\text { fatigue }\end{array}$ & \\
\hline SCHISTOSOMIASIS & $\begin{array}{l}\text { Parasitic flatworms- } \\
\text { schistosomes }\end{array}$ & $\begin{array}{l}\text { Pain abdomen, diarrhea, } \\
\text { bloody stool, blood in the } \\
\text { urine. Long time affection } \\
\text { leads to liver, kidney and } \\
\text { bladder damage. }\end{array}$ & \\
\hline
\end{tabular}

Mechanical hazards:

The mechanical hazards in industry centre round machinery, protruding, and moving parts etc. About $10 \%$ of accidents in industry are said to be due to mechanical causes. Also working for long hours in non-physiological postures is the cause of fatigue, backache, diseases of joints and muscles and impairment of the worker's health and efficiency.

\section{Psychosocial hazards:}

The psychological hazards arise from the workers' failure to adapt to an alien psychological environment. Frustration, lack of job satisfaction, insecurity, poor human relationships, emotional tension are some of the psychosocial factors which may undermine both physical and mental health of the workers. The health effects can be classified into 2 main categories:

\section{Psychological and behavioral changes:}

Includes hostility, aggressiveness, anxiety, depression, alcoholism, drug abuse etcetera. 


\section{Psychosomatic illhealth:}

Includes fatigue, headache, pain in the shoulders, neck and back; tendency to get afflicted with peptic ulcer, hypertension, heart disease and rapid ageing.

\section{Occupational hazards in ayurveda:}

There are various references in the vast Ayurvedic texts about this. Some of those are considered here:

सदाऽsतुराः श्रोत्रियराजसेवकास्तथैव वेश्या सह पण्यजीविभिः ॥२७॥ This is a verse from the $11^{\text {th }}$ chapter of Charaka Samhitha, Kalpa Sthana ${ }^{3}$, which indicates that the above mentioned 4 types of people are always prone to ill health by virtue of their professions. They are:

\section{श्रोत्रिय-}

Vedic priests, ever busy in chanting holy hymns fail to attend the regimens good for their health, instead they always suppress the natural urges, never take food on time, untimely voiding of stools and urine and other untimely regimens.

\section{राजसेवक-}

They forego the healthy regimens as they are always busy in their work of providing protection to the king.

\section{वेश्य-}

A courtesan has to comply to the wishes of the men and their entertainment, hence fails to take care of her health.

\section{पण्यजीवि-}

Merchants lead a very sedentary lifestyle, again because of their profession, hence prone to diseases.

1. Management of diseases in the above mentioned four kinds of people is by the administration of 'Phala sarpi'. This pacifies the aggravated vata dosha because of suppression of urges and also cures vibandha and sarvangaruja.

2. Acharya Sushrutha has mentioned the following factors as causatives of the aupasrgika rogas: gatra sparsha, nishwasa, saha bhojana, saha shayya-asana, vastra mala anulepa leading to diseases like kushta, jwara, shosha and netra abhishyanda. ${ }^{4}$ According to this reference, these diseases spread from one human to another. These can be compared to the biological hazards.

3. In the Chikitsa Sthana of Charaka Samhitha, various references are seen related to this in the Vata vyadhi Chikitsitam adhyaya: ${ }^{5}$

\section{दुःखश्यसनात्-}

Improper sitting or seating arrangements at the work place leads to vata dosha prakopa, thereby leading to many diseases.

\section{गज-उष्ट्र-अश्व शीघ्रयानापतंसनात्-}

Occupations involving travelling excessively like drivers, or when they fall from a height from fast moving vehicles, will be victims of many vata doshajanya vyadhis.

One more reference is from the $29^{\text {th }}$ chapter of Chikitsa Sthana of Charaka Samhitha, in which Vata-rakta disease is explained:

\section{अभिघातात्-}

The disease Vata-rakta is caused is caused by injury. This can be compared with the traumatic injuries witnessed in the factories or big industries

\section{PRE-PLACEMENT EXAMINATION ACCORDING TO AYURVEDA}

Date and Time of examination: 
- NAME:

Place of examination:

- AGE AND DATE OF BIRTH:

- GENDER:

- PLACE OF ORIGIN(Bhoomidesha):

\begin{tabular}{|l|l|l|l|}
\hline PRAKRUTHI: & \multicolumn{3}{|c|}{ मानसिक प्रकृति\% * } \\
\cline { 2 - 4 } & \begin{tabular}{|l|l|l|} 
सात्त्विक \\
काय
\end{tabular} & राजसिक काय & $\begin{array}{l}\text { तामसिक } \\
\text { काय }\end{array}$ \\
\hline
\end{tabular}

- GENERAL EXAMINATION OF THE BODY(Dehadesha):
a) Ayama:
b) Vistara:

Ashta Sthana Pariksha:

1. SAARA PARIKSHA:***

\begin{tabular}{|l|l|l|l|l|l|l|l|}
\hline नाडी & मूत्र & मल & जिस्वा & शब्द & स्पर्श & द्क & आकृति \\
\hline
\end{tabular}

\begin{tabular}{|l|l|l|l|l|l|l|l|}
\hline त्वक् & रक्त & मांस & मेद & अस्थि & मज्जा & शुक्र & स्त्त्व \\
\hline & & & & & & & \\
\hline
\end{tabular}

2.

DASHA PRAANAYATANA PARIKSHA:

\begin{tabular}{|l|l|l|l|l|l|l|l|l|l|}
\hline मूर्धा & कण्ठ & हृदय & नाभि & गुद & बस्ति & ओज & शुक्र & शोणित & मांस \\
\hline & & & & & & & & & \\
\hline
\end{tabular}

3. OTHER SPECIFIC FEATURES EXAMINED BY ANUMANA AND PRATYAKSHA PRAMANAS:

Sign of the physician

\section{Conclusion:-}

1. Pre disposition to occupational hazards can be checked by assessing an individual using Ayurvedic principles and tools.

2. In relation to environment of individual i.e., prakriti, to the environment he or she is exposed to so as to work on a preventive level and to have a decrease in prevalence rate of these occupational diseases.

3. We can apply this knowledge with an intention of screening the individuals.

4. * Based on the inherent prakriti of an individual, he can be assigned a specific profession that is unique to him and complements his constitution.E.g.: A person of Vata prakriti may be given a job that involves good oration, while a Pitta prakriti person fares well in valorous jobs and a Kapha prakriti person excels in statesmanship.** The psychological make-up of an individual also plays a crucial role in the selecting and excelling in the workfront. E.g.: A person of Gandharva Kaya should be encouraged and allowed to pursue feats in the arts/music/dance/ /fashion/ creative arenas.By doing this maximum productivity is attained both by the individual and by the society at large.

5. The Sara pariksha is an excellent assessment tool for both qualitative as well as quantitative status of an individual. This is a very excellent contribution by Ayurvedic science.

6. There are numerous references in Ayurveda indicating that the topic of occupational hazard was well studied and developed a long time back: Charaka Samhitha explains the ideal hospital set-up and in Sushrutha Samhitha, Vranitagara is explained. This shows that the occupational hazards encountered by medical professionals were well taken care of and the zoonotic diseases were controlled. Also explains the dimensions of each and every unit in a Chikitsalaya and the furnitures and fixtures used. This is nothing but Ergonomics, explained far back.

7. Various types of Dhupana formulations show the prowess of our Acharyas in the field of disinfection.

8. Most importantly, in Ayurveda, any occupation was considered as a material means (artha) to attain deliverance (moksha). Thus the spiritual, emotional, and physical aspects of an occupation are dealt here. 
9. Thus, it can be concluded that Ayurveda has a wholesome and holistic approach in the understanding and management of occupational hazards and occupational health.

\section{References:-}

1. Park K. Occupational health. PARK'S TEXTBOOK OF PREVENTIVE AND SOCIAL MEDICINE, Reprint edition 1997. Jabalpur, Madhya Pradesh: M/s Banarsidas Bhanot; 1997. p. 542, $550,542$.

2. https://oem.bmj.com > content > suppl_2.

3. Acharya Agnivesha. Phalamatra siddhi adhyaya 11/27-30. In, Vaidya Yadavji Trikamji Acharya(ed). Charaka Samhitha revised by Acharya Charaka and Dridhbala with Ayurvedadipika commentary by Sri Chakrapanidatta, Reprint edition 2011. Varanasi: Chaukhamba Surbharati Prakashan; 2011. p. 729.

4. Acharya Sushrutha. Kustha Nidanam 6/33-34. In, Vaidya Yadavji Trikamji Acharya(ed). Sushrutha Samhitha with Nibandha Sangraha commentary of Dalhanacharya, Reprint edition 2012. Varanasi: Chaukhamba Surbharati Prakashan; 2012. p. 289.

5. Acharya Agnivesha. Vatavyadhi chikitsitam adhyaya 28/18. In, Vaidya Yadavji Trikamji Acharya(ed). Charaka Samhitha revised by Acharya Charaka and Dridhbala with Ayurvedadipika commentary by Sri Chakrapanidatta, Reprint edition 2011. Varanasi: Chaukhamba Surbharati Prakashan; 2011. p. 617. 